Gi rask respons på artikler gjennom artikkelens kommentarfelt på tidsskriftet.no. Respons som er postet innen én måned etter at artikkelen er publisert, vurderes for publisering som Brev til redaktøren i papirutgaven.

Redaksjonen forbeholder seg retten til å foreta redaksjonelle endringer.

Forfattere av vitenskapelige artikler har tilsvarsrett, jf. Vancouver-gruppens regler.

\section{Look to Norway!}

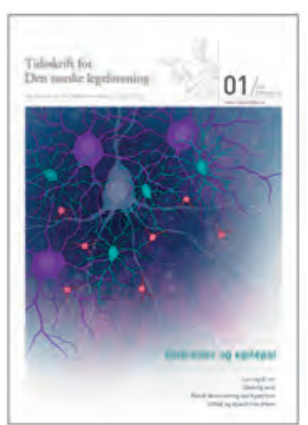

Redaktør Charlotte Haug har i sin leder i Tidsskriftet nr. 1/2014 mye «klok kvinnes tale» (1). Jeg er glad for at vi har en så god analysator av dette helsevesenet vi alle er en del av på en så fremtredende plass i den medisinske offentligheten. Et stikkord for analysen er kompleksitet. Den kinesiske vismannen Laozi skal ha sagt: «Det sammensatte og kompliserte har sine røtter i det enkle.» Jeg tolker: Erkjenne det komplekse, gjøre det enkelt. Er dette en ultrakortform av en bruksanvisning for å få helsevesenet til å virke? Alternativet kan være å bestemme seg for at det er enkelt, uten å ville se kompleksiteten. Det høres mer ut som norsk ikke-såvis-manns-saksbehandler- forvaltnings- tale. Er det rett og slett også på tide å supplere evidensbasert medisin (EBM) med kompleksitetsbasert medisin (complexity based medicine, CBM)? Helt stuerent er det for tiden ikke med god klinisk skjønnsforvaltning.

Jeg er ikke så sikker på hvor langt sammenlikningen med New York rekker. New York er ikke bygd opp rundt et mål om fellesskap der man gjør hverandre gode. Grunnideen i «the big apple» er og blir å smi sin egen lykke. Solidaritets- og rettferdighetskravet ikke bare mangler, men er sett på som noe litt rart.

Finnes det andre velfungerende systemer å se til? Sjekk ut hvilken del av helsevesenet folk selv synes fungerer ok. Fastlegene er nøkkelen, fordi de er små kompetansesentre i kompleksitetsbasert medisin. Blant annet fordi vi nådeløst og hver dag må forsøke å gjøre det enklest mulig.

Jeg vet at det å skryte av seg selv kan virke litt bedrevitersk og kanskje eplekjekt. Veldig nær en tabu. Men jeg tror måten førstelinjemedisinen i Norge er driftet på kan lære både oss og ordføreren i New York mye om smarte grep og rammer.

\section{Harald Sundby}

har-su2@online.no

Harald Sundby (f. 1962) er fastlege ved Kalvskinnet legesenter og universitetslektor ved Norges teknisk-naturvitenskapelige universitet. Ingen oppgitte interessekonflikter.

\section{Litteratur}

1. Haug C. Helsebyen. Tidsskr Nor Legeforen 2014; 134: 5.

Dette er en redigert versjon av debatten, publisert på nett 24.1. 2014. http://tidsskriftet.no/article/3119773/

\section{Spørsmål som allerede er besvart}

I G. Jamtvedt og medarbeideres kommentar i Tidsskriftet nr. 1/2014 (1) proklamerer forfatterne allerede i ingressen: «For å unngå sløsing med begrensede forskningsressurser og spare pasienter for unødig deltakelse i prosjekter bør forskning ikke gjennomføres hvis spørsmålet allerede er besvart.» Mitt spørsmål til forfatterne blir: Nicolaus Copernicus, Andreas Vesalius, Galileo Galilei forsøkte alle tre å besvare spørsmål som allerede var besvart. Burde ikke deres resultater vært publisert?

\section{Torgrim Sørnes}

torgrim.sornes@gmail.com
Torgrim Sørnes (f. 1956) er overlege ved Akershus universitetssykehus, Kvinneklinikken.

Ingen oppgitte interessekonflikter.

\section{Litteratur}

1. Jamtvedt G, Lund H, Nortvedt MW. Kunnskapsbasert forskning? Tidsskr Nor Legeforen 2014; 134: 10-1.

Dette er en redigert versjon av debatten, publisert på nett 1.12. 2013. http://tidsskriftet.no/article/3120042/

\section{H. Lund og medarbeidere svarer:}

Mange tak for kommentaren til vor artikel om kunnskapsbasert forskning (1).

Kunnskapsbasert forskning er et begreb etableret med henblik på at forbedre kvaliteten af den forskning der gennemføres og publiceres. Forudsætningen for god kvalitet i forskning er at forskningsaktiviteten bidrager med nødvendig ny viden, ikke nye spørgsmål. Et forskningsresultat bør kunne reproduceres inden vi i praksis endeligt vælger at følge forskningsresultaterne. Det betyder selvfølgelig at det samme spørgsmål forsøges besvaret flere gange for at vi kan være sikre på at resultatet ikke er en enlig svale, men er troværdigt og holdbart. Forudsætningen for gennemførelse af systematiske oversigtsartikler er netop også at der findes flere studier der søger svar på det samme spørgsmål. Udfordringen er dog at vide hvornår nok er nok. En af de pointer vi ønsker at slå til lyd for med begrebet kunnskapsbasert forskning er netop at udvikle metoder til at finde en troværdig grænse for hvornår der er nok studier der har forsøgt at svare på et bestemt spørgsmål. Til gengæld vil denne indfaldsvinkel kunne give os mulighed for at blive mere specifikke i vore forskningsspørgsmål. Et nyligt publiceret studie viser $\mathrm{fx}$ at allerede i 2002 var vi klar over at fysisk træning kan mindske smerter og forbedre funktionen hos personer med artrose i knæet/ ene (2). Senere studier der forsøger at svare på om træning er effektiv synes derfor overflødige (dem er der nogen stykker af indenfor dette felt). Men vi kan dog ikke på baggrund af de studier identificere hvilke subgrupper der har bedst effekt, hvilke træningsformer der har bedst effekt eller hvilken dosis der er den mest optimale. Dette er nye forskningsspørgsmål som skal besvares, omend de selvfølgelig relaterer sig til det oprindelig spørgsmål om træning er godt til personer med artrose i knæ.

Copernicus, Vesalius og Galilei stillede spørgsmål som man mente var besvaret. Imidlertid var deres specificering af spørgsmålene og metoderne de anvendte at besvare dem med nye og bidrog derfor med ny viden.

Kunnskapsbasert forskning er ikke at finde på nye spørgsmål, men på baggrund af helheden af den eksisterende viden formulere de relevante spørgsmål.

\section{Hans Lund \\ hlund@health.sdu.dk \\ Gro Jamtvedt \\ Monica Nortvedt}

Hans Lund (f. 1958) er lektor ved Syddansk Universitet og professor ved Senter for kunnskapsbasert praksis, Høgskolen i Bergen.

Ingen oppgitte interessekonflikter.

Gro Jamtvedt (f. 1957) er avdelingsdirektør i Nasjonalt kunnskapssenter for helsetjenesten og professor ved Senter for kunnskapsbasert praksis, Høgskolen i Bergen.

Ingen oppgitte interessekonflikter. 